University of Nebraska - Lincoln

DigitalCommons@University of Nebraska - Lincoln

Virology Papers

Virology, Nebraska Center for

2003

\title{
Animal anti-apoptotic genes ameliorate the loss of turgor in water-stressed transgenic tobacco
}

Tala Awada

University of Nebraska-Lincoln, tawada2@unl.edu

D. D. Dunigan

University of Nebraska-Lincoln, ddunigan2@unl.edu

M. B. Dickman

University of Nebraska-Lincoln

Follow this and additional works at: https://digitalcommons.unl.edu/virologypub

Part of the Biological Phenomena, Cell Phenomena, and Immunity Commons, Cell and Developmental Biology Commons, Genetics and Genomics Commons, Infectious Disease Commons, Medical Immunology Commons, Medical Pathology Commons, and the Virology Commons

Awada, Tala; Dunigan, D. D.; and Dickman, M. B., "Animal anti-apoptotic genes ameliorate the loss of turgor in water-stressed transgenic tobacco" (2003). Virology Papers. 243.

https://digitalcommons.unl.edu/virologypub/243

This Article is brought to you for free and open access by the Virology, Nebraska Center for at DigitalCommons@University of Nebraska - Lincoln. It has been accepted for inclusion in Virology Papers by an authorized administrator of DigitalCommons@University of Nebraska - Lincoln. 


\title{
Animal anti-apoptotic genes ameliorate the loss of turgor in water-stressed transgenic tobacco
}

\author{
T. Awada1 , D. D. Dunigan², and M. B. Dickman² \\ ${ }^{1}$ School of Natural Resource Sciences, 12 D Plant Industry, University of Nebraska-Lincoln, Nebraska, \\ 68583-0814 (e-mail: tawada2@ @unl.edu); ' 2 Department of Plant Pathology, University of Nebraska-Lincoln, \\ Nebraska. 68583-0758. A contribution of the University of Nebraska Agricultural Research Division, Lincoln, \\ NE 68583. J.S. No. 13670. Received 15 July 2002, accepted 27 January 2003.
}

Awada, T., Dunigan, D. D. and Dickman, M. B. 2003. Animal anti-apoptotic genes ameliorate the loss of turgor in waterstressed transgenic tobacco. Can. J. Plant Sci. 83: 499-506. Nicotiana tabacum L. 'Glurk' plants were transformed with antiapoptotic animal genes [chicken Bcl-xl; nematode CED-9; chicken Bcl-xl(GA) a mutant of Bcl-xl; and a 3' non-coding region of human Bcl-2, referred to as 161-1]. Our objectives were to determine whether plant transformation with anti-apoptotic genes ameliorates drought tolerance in tobacco plants by subjecting the plants to a dry-down period. The non-transformed Glurk and the transgenic Glurk harboring G115, which expresses $\beta$-glucuronidase, served as controls. Transformation of tobacco plants with animal anti-apoptotic genes significantly impacted the rates of photosynthesis $(A)$ and stomatal conductance $\left(g_{s}\right)$, but not to the same extent in every line. Controls generally exhibited higher $A$ and $g_{s}$ than the transformed plants under well-watered conditions. Photosynthesis and stomatal conductance declined significantly on the 3rd day, and approached zero on the 11th day of water deprivation. Differences among controls and transformed tobacco plants disappeared as soil moisture deficit increased. Relative water content $(\mathrm{RWC})$ and leaf water potential $\left(\Psi_{\mathrm{w}}\right)$ remained relatively high in the first $3 \mathrm{~d}$ of water deprivation, while a dramatic reduction occurred in all plants on the 6th day. Relative water content did not differ between controls and transformed plants. Water potential declined significantly (became more negative) with the increase in soil moisture deficit. Evident differences among transformed and control plants appeared on the 6th day of water deprivation. The controls, Glurk and G115 generally maintained a higher water potential between days 6 and 11 compared to the transformed tobacco plants. Osmotic adjustment occurred in transformed plants but not in the controls, in response to drought. Relative water content at turgor loss point $\left(\mathrm{RWC}_{\text {tlp }}\right)$ and osmotic potential at turgor loss point $\left(\Psi_{\pi \mathrm{tlp}}\right)$ provided a measure of drought tolerance in plants. G115, Glurk and Bcl-xl plants lost turgor at a higher relative water content than Bcl-xl(GA), CED-9 and 161-1. $\Psi_{\pi t l p}$ in the controls G115 and Glurk were relatively higher compared to the transformed plants. We concluded that transgenic plants with anti-apoptotic genes resulted in moderate amelioration of drought tolerance in tobacco plants.

Key words: Anti-apoptotic genes, programmed cell death, genetic engineering, Nicotiana tabaccum, drought tolerance, gas exchange, photosynthesis, turgor, osmotic adjustment

\begin{abstract}
Awada, T., Dunigan, D. D. et Dickman, M. B. 2003. Les gènes anti-apoptose des animaux atténuent la perte de turgescence chez le tabac transgénique lors d'un stress hydrique. Can. J. Plant Sci. 83: 499-506. Des plants du cultivar Glurk de Nicotiana tabacum L. ont été transformés par addition de gènes animaux contre l'apoptose (Bcl-xl du poulet; CED-9 des nématodes; Bcl$\mathrm{xl}(\mathrm{GA})$ du poulet, un mutant de Bcl-xl; séquence non codante de 3' du gène humain Bcl-2 baptisée 161-1). Pour déterminer si une telle transformation améliore la résistance des plants à la sécheresse, les auteurs ont privé ceux-ci d'eau. Les plants Glurk non transformés et les plants transgéniques G115 exprimant la $\beta$-glucoronidase ont été utilisés comme témoins. L'introduction de gènes animaux anti-apoptose dans les plants de tabac a une incidence significative sur la photosynthèse $(A)$ et sur la conductivité des stomates $\left(g_{s}\right)$, mais pas dans la même mesure, selon la lignée. En général, les témoins présentent une $A$ et une $g_{s}$ supérieures à celles des plants transformés quand il y a suffisamment d'eau. La photosynthèse et la conductivité des stomates diminuent sensiblement le $3^{\mathrm{e}}$ jour et approchent la valeur nulle dès le $11^{\mathrm{e}}$ jour de sécheresse. La différence entre les témoins et les plants transformés s'atténue avec la progression du déficit hydrique dans le sol. La teneur relative en eau $(R W C)$ et le potentiel hydrique des feuilles $\left(\Psi_{\mathrm{w}}\right)$ restent relativement élevés les trois premiers jours de sécheresse, mais diminuent fortement le $6^{\mathrm{e}}$ jour. La teneur relative en eau était la même pour les témoins et les plants transgéniques. Le potentiel hydrique baisse sensiblement (devient plus négatif) quand le manque d'eau augmente dans le sol. Des différences manifestes entre les plants témoins et les plants transformés surgissent le $6^{\mathrm{e}}$ jour de sécheresse. Du $6^{\mathrm{e}}$ au $11^{\mathrm{e}}$ jour de sécheresse, les témoins Glurk et $\mathrm{G} 115$ se caractérisent habituellement par un meilleur potentiel hydrique que les plants transgéniques. La privation d'eau entraîne une modification de l'osmose chez les plants transgéniques, mais pas chez les témoins. La teneur relative en eau au point de perte de la turgescence $\left(\mathrm{RWC}_{\mathrm{tlp}}\right)$ et le potentiel osmotique au même point $\left(\Psi_{\pi t l p}\right)$ permettent d'évaluer la tolérance des plants à la sécheresse. G115, Glurk et les plants Bcl-xl perdent leur turgescence à une teneur relative en eau plus élevée que les plants Bcl-xl(GA), CED-0 et 161-1. Les témoins ont un $\Psi_{\pi t l p}$ relativement plus élevé que les plants transgéniques. On en conclut que le transfert des gènes contre l'apoptose entraîne une légère amélioration de la résistance des plants de tabac à la sécheresse.
\end{abstract}

Mots clés: Gènes anti-apoptose, mort programmée des cellules, génie génétique, Nicotiana tabacum, résistance à la sécheresse, échanges gazeux, photosynthèse, turgescence, correction de l'osmose

Abbreviations: A, net photosynthesis; $\mathbf{g}_{\mathrm{s}}$, stomatal conductance; $\Psi_{\pi \mathrm{tl}}$, osmotic potential at turgor loss point; ROS, reactive oxygen species; RWC, relative water content 
Water deficit is one of the major limiting factors for plant growth and productivity around the world (Karakas et al. 1997). Water stress in plants occurs when transpirational demands exceed water absorption by roots, affecting enzymatic reactions and physiological processes. The extent to which a plant experiences water stress depends on the inherent drought resistance of the plant and the prevailing environmental conditions. The first and most sensitive response to water stress is a decrease in leaf turgor, which reduces cell elongation. This is followed by a decrease in protein synthesis and cell division. The lag of stomatal closure behind loss in turgor is the primary cause for reductions in photosynthesis under short-term drought (Chaves 1991) or mild water stress (Du et al. 1998). Under severe drought, reductions in biochemical reactions generally follow reductions in photosynthetic capacity (Tezara et al. 1998). Plants have evolved various strategies to cope with drought stress, undertaking a variety of biochemical and physiological changes (Levitt 1980). Although genetic differences exist among different plant species regarding stress tolerance, it is agreed that cultivated crops are usually very sensitive to water stress (Bajaj et al. 1999). Genetic engineering can potentially play a fundamental role in achieving long-term tolerance to drought stress.

Interest in programmed cell death has increased exponentially over the past few years because of its important role in the development of higher eukaryotic cells, tissue homeostasis, and protection against pathogens (Adams and Cory 1998). Programmed cell death can be triggered to induce death either in cells that are no longer needed at a certain phase of plant development, or in response to attack by pathogens such as viruses, fungi and bacteria (Dickman et al. 2001). Programmed cell death regulation has the potential to be used to improve crop quality, identify genes involved in disease resistance, and improve stress tolerance in plants (Kreeger 1996). Transgenic plants transformed with genes that negatively regulate apoptosis (genes that suppress cell death), such as those expressing chicken Bcl$\mathrm{xl}$, and the nematode CED-9 genes, were found to confer heritable resistance to several necrotrophic fungal pathogens and to tomato spotted wilt virus (Dickman et al. 2001). Also, a 3' non-coding region of human Bcl-2 mRNA conferred a similar phenotype. Bcl-xl and CED-9 were also found to protect tobacco from cell death induced by either UV radiation or paraquat treatment (Mitsuhara et al. 1999). The mechanism of action of these anti-apoptotic genes is still a matter for speculation (Dickman et al. 2001). Adams and Cory (1998) proposed that Bcl-2 can prevent cell death in a number of ways including: preventing cytochrome $\mathrm{c}$ release from mitochondria, preventing oxygen-induced cell death, dimerizing with and inactivating death promoting apoptotic proteins, and by sequestering caspase-activating proteins.

Programmed cell death pathways are induced in animal cells in response to wide array of environmental stresses including rapid thermal and osmotic changes, toxins, pathogens, or damaging radiation. These types of stressors are associated with the generation of reactive oxygen species (ROS). Several animal anti-apoptotic genes are associated with the mitigation of these stress-induced cell deaths, particularly the Bcl-2 family members (Gross et al. 1999), and thus appear to have overlapping stress-mitigating functions. To evaluate the potential conservation of cell survival pathways between plants and animals, we have generated and partially characterized tobacco plants expressing certain members of the Bcl-2 family. These plants were shown to confer a significant level of resistance to a selected set of plant pathogens (Dickman et al. 2001). In the course of evaluating these transgenic tobaccos, it was noticed that leaves from the anti-apoptotic gene expressing plants were tolerant to brief periods of water deficit, relative to the control plants. Inasmuch that drought-treated plants develop relatively high levels of ROS (Price et al. 1989; McKersie et al. 1996; Oberschall et al. 2000) and/or ROS indicators, including glutathione transferase/peroxidase (Bianchi et al. 2002), we hypothesized that these plants would have enhanced tolerance to water deficit conditions by interfering with ROS mediated cell death. Our objective was to determine whether plant transformation with animal anti-apoptotic genes ameliorate drought tolerance in tobacco plants.

\section{MATERIALS AND METHODS}

\section{Plant Materials and Growth Conditions}

Nicotiana tabacum L. 'Glurk' plants were transformed by Dickman et al. (2001) with one of the three negative regulators of apoptotic genes: (1) human Bcl-2 mRNA sequence 725-1428 representing a 3' non-coding region of the gene and shown to confer a type of resistance to certain pathogens (human Bcl-2 mRNA obtained from $\mathrm{S}$. Korsmeyer, Dana-Faber Cancer Institute, Boston) (Yang and Korsmeyer 1996), referred to as 161-1; (2) chicken Bclxl (obtained from C. Thompson, University of Chicago) (Boise et al. 1993); (3) C. elegans CED-9, which suppresses development of programmed cell death in nematode (obtained from H. Horvitz, Massachusetts Institute of Technology, Cambridge) (Hengartner and Horvitz 1994); (4) chicken Bcl-xl(GA), a mutant of Bcl-xl, the exchange of the amino acid ( $\mathrm{G}$ to $\mathrm{A}$ ) at position 138 disables the phenotype of Bcl-xl by interfering with dimerization; and (5) G115, the plasmid transformation vector which contains $\beta$-glucuronidase. The non-transformed Glurk tobacco and G115 served as controls. All plants (wild type and transgenic) were similar in morphology and development.

The tobacco lines used were all from original transformants and were vegetatively propagated. In our initial studies, we screened a minimum of three independent events per transgene and 10 lines per event, and specifically chose plant that expressed a low (1-2) copy number of insertions, as determined by DNA blots. Lines were also chosen based upon normal morphological development. There was a perfect correlation between phenotype and genotype.

Four-week-old tobacco plants were transferred to pots filled with Cornell Mix. Plants were grown in the greenhouse for $8 \mathrm{wk}$ under ambient light conditions at a relative humidity of $50 \%$ and at $22: 26^{\circ} \mathrm{C}$ day:night temperatures. A total of 90 individuals with relatively identical height $(70-80 \mathrm{~cm})$ were chosen for the study. Plants were distrib- 


\begin{tabular}{|c|c|c|c|c|c|c|c|c|c|c|c|}
\hline & \multirow[b]{2}{*}{ df } & \multicolumn{2}{|c|}{$\mathrm{A}$} & \multicolumn{2}{|c|}{$\mathrm{g}_{\mathrm{s}}$} & \multicolumn{2}{|c|}{ RWC } & \multicolumn{2}{|c|}{$\Psi_{w}$} & \multicolumn{2}{|c|}{ Soil moisture } \\
\hline & & $\mathrm{F}$ & $\mathrm{P}$ & $\mathrm{F}$ & $\mathrm{P}$ & $\mathrm{F}$ & $\mathrm{P}$ & F & $\mathrm{P}$ & $\mathrm{F}$ & $\mathrm{P}$ \\
\hline \multicolumn{12}{|l|}{ Repeated measures analyses } \\
\hline Date (D) & 5 & 242.3 & $<0.0001$ & 52.1 & $<0.0001$ & 236.5 & $<0.0001$ & 642.4 & $<0.0001$ & 1329.1 & $<0.0001$ \\
\hline Variety (V) & 5 & 7.14 & $<0.0001$ & 3.37 & $<0.0063$ & 1.81 & 0.117 & 7.45 & $<0.0001$ & 1.25 & 0.400 \\
\hline $\mathrm{D} \times \mathrm{V}$ & 25 & 2.91 & 0.0004 & 2.20 & $<0.0079$ & 1.12 & 0.337 & 1.29 & 0.201 & 0.65 & 0.864 \\
\hline \multicolumn{12}{|l|}{ Orthogonal contrasts $\mathbf{y}^{\mathbf{y}}$} \\
\hline $\begin{array}{l}\text { (Glurk G115) vs. (161-1 } \\
\text { Bcl-x1 Bcl-x1(GA) CED-9) }\end{array}$ & 172 & 9.75 & 0.002 & 3.19 & 0.007 & 4.24 & 0.04 & 12.3 & $<0.0001$ & & \\
\hline \multicolumn{12}{|l|}{ Glurk vs. G115 } \\
\hline Bcl-x1 vs. Bcl-x1(GA) & 172 & 15.24 & $<0.0001$ & 6.61 & 0.011 & & & & & & \\
\hline 161-1 vs. Bcl-x1 & 172 & 10.56 & 0.001 & 7.86 & 0.005 & & & & & & \\
\hline 161-1 vs. Bcl-x1(GA) & 172 & & & & & & & 12.46 & 0.006 & & \\
\hline \multicolumn{12}{|l|}{ 161-1 vs. CED-9 } \\
\hline CED-9 vs. Bcl-x1 & 172 & 7.05 & 0.009 & & & & & 10.91 & 0.001 & & \\
\hline CED-9 vs. Bcl-x1(GA) & 172 & & & & & & & 23.42 & $<0.0001$ & & \\
\hline
\end{tabular}

zumbers in bold are statistically significant at $P<0.05$.

yonly significant interactions were reported.

uted randomly between two blocks, and pots were spaced at $25-30 \mathrm{~cm}$. Soil moisture deficit was then initiated by withholding water. Soil moisture levels were monitored in all pots using time domain reflectometry technology ( $\mathrm{TH} 2 \mathrm{O}$ portable soil moisture meter, Dynamax Inc., Houston, TX) to ensure uniformity in soil moisture content among pots throughout the study.

\section{Photosynthesis and Stomatal Conductance}

Maximum net photosynthesis $\left(A, \mu \mathrm{mol} \mathrm{m} \mathrm{m}^{-2} \mathrm{~s}^{-1}\right)$ and stomatal conductance $\left(g_{s}, m^{-2} \mathrm{~s}^{-1}\right)$ at light saturation were followed using a portable photosynthetic system mounted with a LED light source (LI 6400-2B, LICOR Inc. Lincoln, NE) between 1100 and 1400. $A$ and $g_{s}$ were measured on leaves 16-23 from the base throughout the dry-down period at 2- to 3-d intervals. Measurements were conducted at an air temperature of $25-26^{\circ} \mathrm{C}$, relative humidity of $45 \%$ and photosynthetic active radiation equal to $1200 \mu \mathrm{mol} \mathrm{m} \mathrm{m}^{-2} \mathrm{~s}^{-1}$.

\section{Relative Water Content and Water Potential}

Relative water content (RWC, \%) of the leaves [RWC = ((fresh weight - dry weight) / (turgid weight-dry weight) $) \times$ 100] was determined on the same leaves used for gas exchange measurements. Water potential $\left(\Psi_{\mathrm{w}}, \mathrm{MPa}\right)$ of the leaves was measured using a pressure chamber (PMS Instruments, Corvallis, OR). Pressure-volume (P-V) curves were created and osmotic potential at turgor loss point $\left(\Psi_{\pi \mathrm{tlp}}\right)$ and relative water content at turgor loss point $\left(\mathrm{RWC}_{\mathrm{tlp}}\right)$ were derived from these curves (Hinckley et al. 1980).

\section{Statistical Analysis}

Repeated measures analyses were used to evaluate plant responses to the dry-down period or water deprivation. The data were analyzed using the Mixed Models Procedure in SAS (SAS Institute, Inc. 1996). Blocks were considered random, and lines and dates were considered fixed. Pairwise means comparisons were performed using the probability of difference (Pdiff statement in SAS, $P<0.05$ ) (Steel et al. 1997). Orthogonal contrasts were performed for each of these analyses of variances: transformed tobacco vs. controls, among controls, and among transformed tobacco.

\section{RESULTS}

\section{Soil Moisture}

Soil moisture content expressed as percent of field capacity was measured throughout the dry-down period to ensure uniformity in soil moisture in pots. Soil moisture decreased from $92 \%$ of field capacity, $1 \mathrm{~d}$ after water deprivation to $10 \%$ after $13 \mathrm{~d}$. Repeated measures analyses indicated that while soil moisture in pots declined significantly over time, pots of different tobacco plants did not differ significantly from each other within dates (Table 1, Fig. 1).

\section{Photosynthesis and Stomatal Conductance}

Maximum photosynthetic rates $(A)$ and stomatal conductance $\left(g_{s}\right)$ at light saturation were measured before and during the dry-down period. Transformation of tobacco plants with animal anti-apoptotic genes significantly impacted the rates of $A$ and $g_{\mathrm{s}}$ but not to the same extent in every line. Under well-watered conditions (day 1), $A$ was 45 and $25 \%$ higher in the non-transformed Glurk than in the transformed Bcl-xl(GA) and 161-1 (Fig. 2a). Photosynthesis was also slightly higher in Glurk than the control G115, and the transformed Bcl-xl and CED-9, but differences were not significant. Drought stress induced significant changes in $A$ (Table 1). Photosynthetic rates declined by approximately $40 \%$ in $161-1$ and CED-9 and by 13 to $20 \%$ in Bcl-xl, Bclxl(GA), G115 and Glurk on the 3rd day of water deprivation. Photosynthesis continued to decline with the increase in drought stress, and approached zero on the 11th day of water deprivation, except in the transformed Bcl-xl and Bcl$\mathrm{xl}(\mathrm{GA})$ where losses due to respiration exceeded the gain 


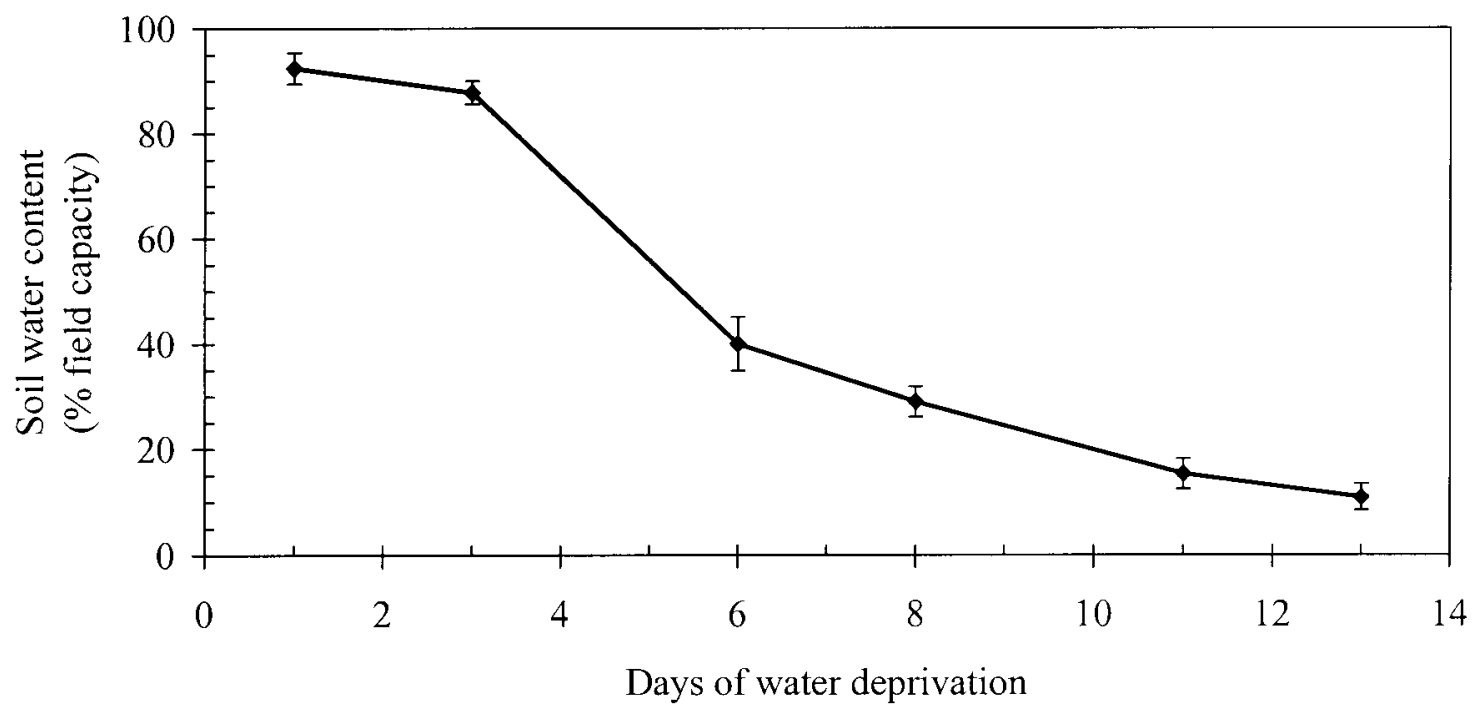

Fig. 1. Average soil moisture content expressed as percent of field capacity and standard error bars during a dry-down period in pots of tobacco plants growing in the greenhouse.

from photosynthesis. Differences in photosynthetic trends among transformed and non-transformed tobacco plants were analyzed using orthogonal contrasts. Trends in the controls G115 and Glurk were similar but were significantly different from the transformed tobacco Bcl-xl(GA), Bclxl, CED-9 and 161-1 (Table 1).

Similar to $A$, plant transformation impacted $g_{s}$ rates; however, differences among lines were only significant on day 1. Under well-watered conditions, stomatal conductance was significantly lower in the transformed Bcl-xl(GA) and 161-1 than in the remaining lines (Fig. 2b). Stomatal conductance declined significantly with the increase in drought stress; however, differences among controls and transformed tobacco plants disappeared as soil moisture deficit increased. The decline in stomatal conductance was steep on 3 rd day of water deprivation in Glurk, G115 and Bcl-xl (31, 37 and $51 \%$, respectively). Stomatal conductance continued to decrease and stomata were almost completely closed on the 11th day of water deprivation.

\section{Relative Water Content and Water Potential}

Relative water content of leaves was significantly impacted by drought (Table 1, Fig. 3). Transformed and control plants, responded in a similar manner to water deficit. RWC dropped from $90 \%$ in well-watered plants to $10 \%$ after $13 \mathrm{~d}$ of water deprivation. Leaf water potential remained relatively high (less negative) in the first $3 \mathrm{~d}$ of water deprivation, a dramatic reduction occurred in all plants on the 6th day. Water potential continued to decline significantly (became more negative) with the increase in soil moisture deficit. Evident differences among transformed and control plants started appearing on the 6th day of water deprivation. The controls, Glurk and G115 generally maintained a higher (less negative) water potential between days 6 and 11 compared to the transformed tobacco plants. Water potentials were generally lowest in Bcl-xl(GA). Differences among transformed and controls disappeared on the 13th day of water deprivation.

Relative water content at turgor loss point $\left(\mathrm{RWC}_{\mathrm{tlp}}\right)$ and osmotic potential at turgor loss point $\left(\Psi_{\pi \mathrm{tlp}}\right)$ provide a measure or relative ranking of drought tolerance in plants. There was no sharp distinction between or within transformed and non-transformed or control plants. G115, Glurk and Bcl-xl plants lost turgor at a relatively higher relative water content than Bcl-xl(GA) and CED-9. 161-1 exhibited the lowest $\mathrm{RWC}_{\text {tlp }} \cdot \mathrm{G115}$, Glurk and CED-9 also had the highest (less negative) $\Psi_{\pi \mathrm{tlp}}$ compared to the others (Fig. 4)

\section{DISCUSSION}

Photosynthesis $(A)$ and stomatal conductance $\left(g_{s}\right)$ measurements provided important information on the utilization efficiency of environmental resources in controls and transformed plants. Transgenic tobacco exhibited physiological changes in $A$ and $g_{s}$, particularly in $\mathrm{Bcl}-\mathrm{xl}(\mathrm{GA})$ and to a lesser extent in 161-1. Dickman et al. (2001) reported undetectable morphological or physiological changes in lines expressing Bcl-2, Bcl-xl or CED-9. Our results are in general agreement with Dickman et al. (2001) for these lines, it is, however, unclear whether the mutation of Bcl-xl with the addition of an amino acid is behind the decline in $A$ and $g_{s}$. Transformation of tobacco has been shown to affect gas exchange rates, for example Patchepsky et al. (1997) suggested that transformation resulted in anatomical and metabolic differences that affected photosynthetic and transpiration rates in tobacco plants.

Drought stress induced a significant and rapid decline in $A$ and $g_{s} 3 \mathrm{~d}$ after the initiation of water stress. The decline in $R W C$ and $\Psi_{\mathrm{w}}$ lagged behind the $A$ and $g_{s}$, observed on the 6 th day of water deprivation. Krampitz and Fock (1984) suggested that in the early stages of drought dehydration stomatal closure results in a decrease in total carbon assimilation, at this stage, electron transport, mitochondrial activ- 
$\mathbf{a}$

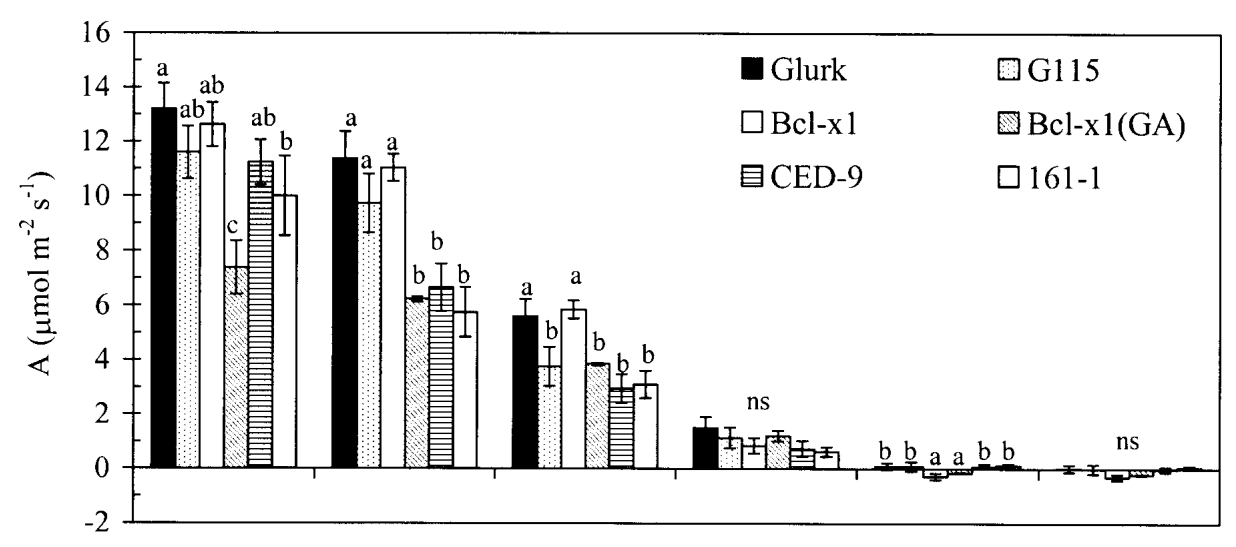

b

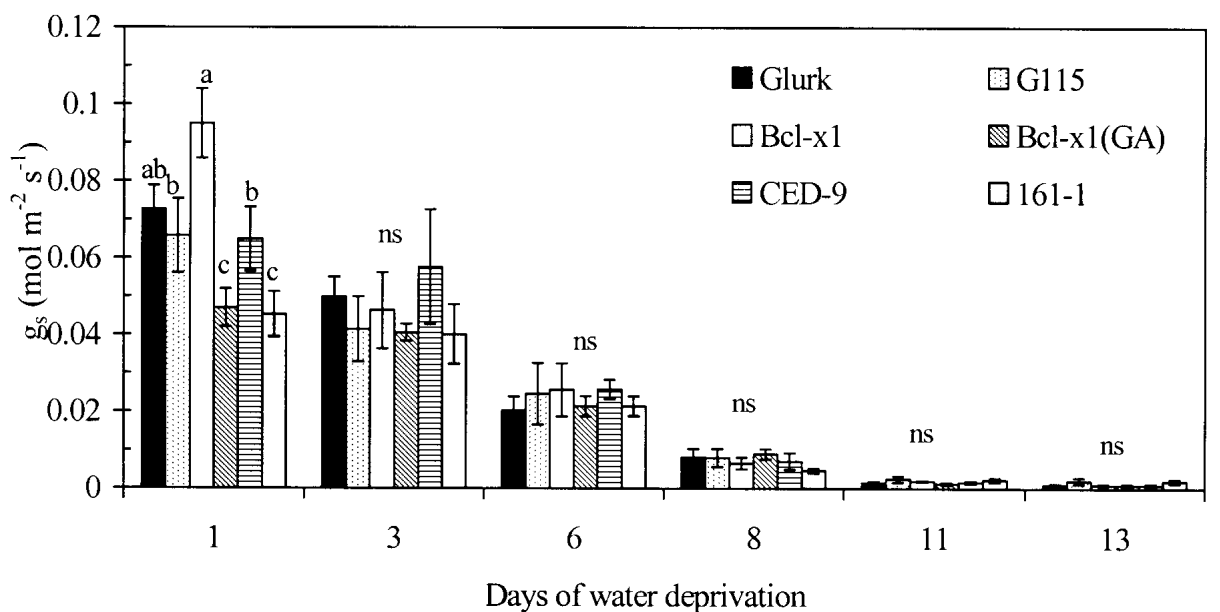

Fig. 2. Average maximum photosynthetic rates $\left(A, \mu m o l m^{-2} \mathrm{~s}^{-1}\right)$ (a) stomatal conductance $\left(\mathrm{g}_{\mathrm{s}}, \mathrm{mol}^{-2} \mathrm{~s}^{-1}\right)$ (b) and standard error bars in transformed [161-1, Bcl-x1, Bcl-x1(GA) and CED-9] and controls (Glurk and G115) tobacco plants during a dry-down period in the greenhouse. Bars with the same letters within a date are not statistically different at $P<0.05$.

ity and photorespiration are still active. Similarly, FerrarioMéry et al. (1998) found that $A$ decreased significantly after the 2nd day of water deprivation, and declined by $70 \%$ after $4 \mathrm{~d}$ of water deprivation in both transformed tobacco expressing nitrate reductase and non-transformed tobacco plants. The authors added that the decline in water contents of leaves lagged behind $A$ and $g_{s}$ and was observed $5 \mathrm{~d}$ after water deprivation in both tobacco lines. Alfalfa plants retained relatively constant leaf water potential in the first 3 $\mathrm{d}$ after withholding water. A drastic decline in water potential was recorded $5 \mathrm{~d}$ after withholding water (McKerise et al. 1996).

The decline in leaf $\Psi_{\mathrm{w}}$ in response to water stress does not directly affect the metabolism of plants, but it is a good indicator of a plant water status. RWC decline on the other hand can be directly related to the inhibition of plant functions (Berkowitz 1998). Plants may acclimate to water stress by osmotic adjustment, which is achieved by maintaining turgor at lower water potential. Therefore, relative water content at turgor loss point $\left(\mathrm{RWC}_{\mathrm{tlp}}\right)$ and osmotic potential at turgor loss point $\left(\Psi_{\pi t l p}\right)$ provide a measure of drought tolerance in plants. The lower the $\mathrm{RWC}_{\mathrm{tl}}$, and the more negative the $\Psi_{\pi t \mathrm{l}}$, the more drought resistant is the plant. The controls G115, Glurk lost turgor at both higher RWC and osmotic potential than the transformed lines, indicating that the controls were not as drought tolerant as the transformed lines.

Transgenic gene expression, however, did not enhance or ameliorate drought resistance in all transformed lines to the same extent. Our results indicated that plants with the 
a

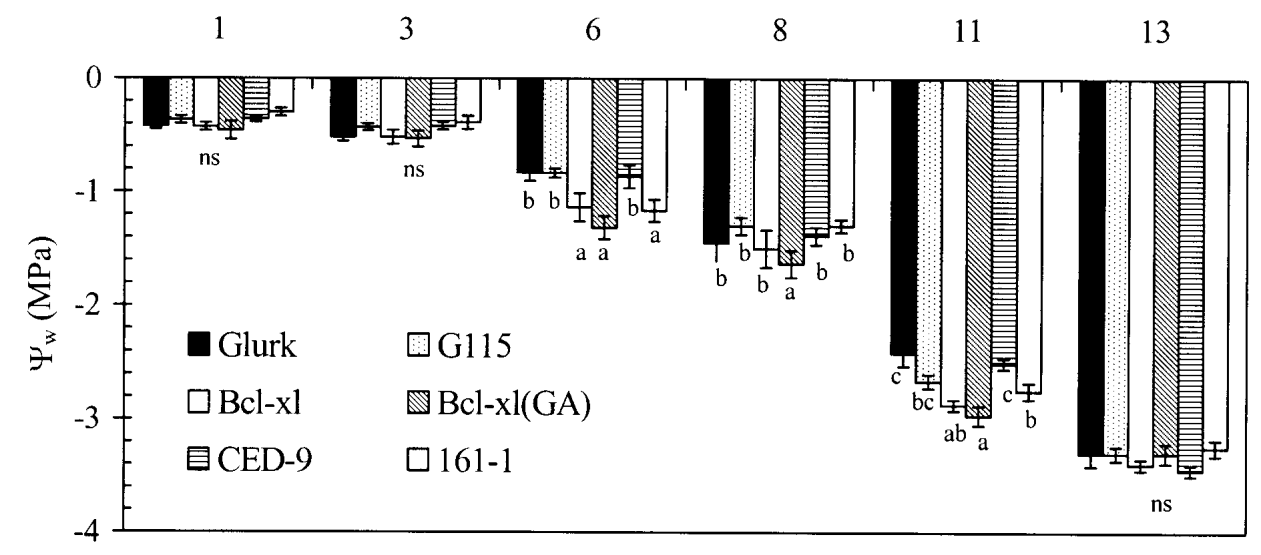

b

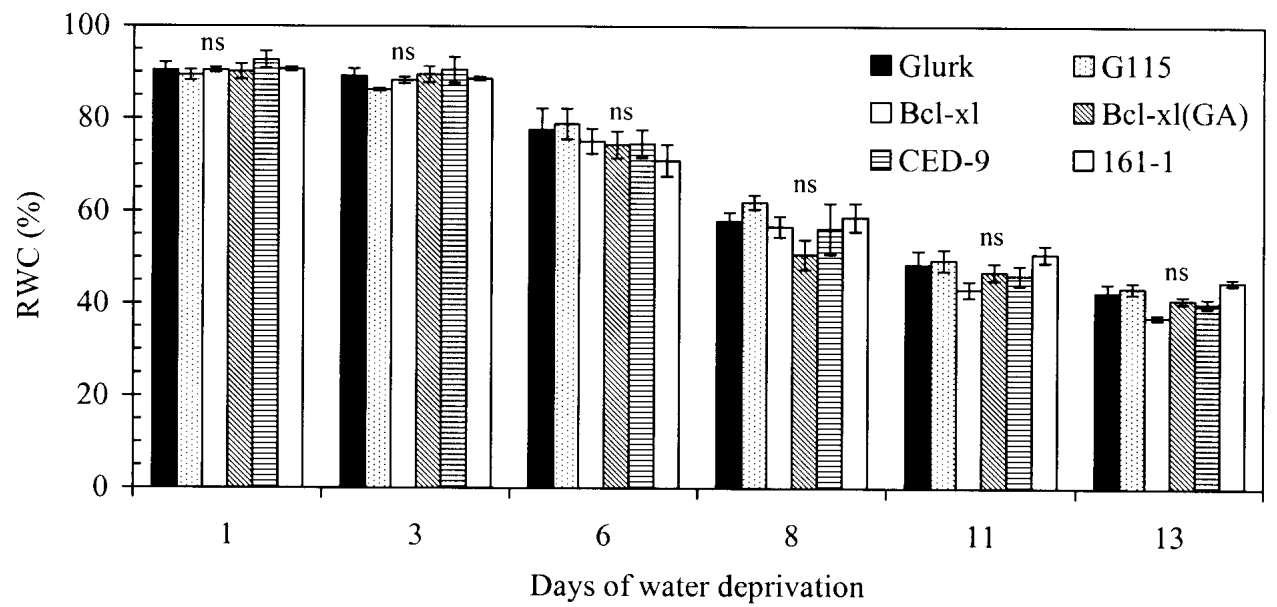

Fig. 3. Average leaf water potential ( $\left.\Psi_{w}, \mathrm{MPa}\right)(\mathrm{a})$ and relative water content (RWC, \%) (b) and standard error bars in transformed [161-1, Bcl-x1, Bcl-x1(GA) and CED-9] and controls (Glurk and G115) tobacco plants during a dry-down period in the greenhouse. Bars with the same letters within the same date are not statistically different at $P<0.05$.

human 161-1 genes were generally distinct from the other transformed lines by losing turgor at a significantly lower relative water content than the others. Also, 161-1, in addition to BCL-xl and Bcl-xl(GA), exhibited the lowest (more negative) $\Psi_{\pi \mathrm{lp}}$. Redfield and Zwiazek (2000) reported that a decrease in $\mathrm{RWC}_{\mathrm{tlp}}$ and $\Psi_{\pi \mathrm{lp}}$ of $6 \%$ and 0.3 , respectively, ameliorated drought resistance in seedlings. Similarly, Augé et al. (1986) found that drought acclimated Rosa hybrida had a $\Psi_{\pi t l p}$ of 0.4-0.6 less than non acclimated plants. In the current study, $\mathrm{RWC}_{\mathrm{tlp}}$ and $\Psi_{\pi \mathrm{tlp}}$ were 6 and $0.2 \%$ lower in 161-1 than in the non-transformed Glurk plants. It seems that transformation improved plant capability of osmotic adjustment especially in plants with 161-1, BCL-xl and Bcl$\mathrm{xl}(\mathrm{GA})$ and to a lesser extent in plants with CED-9 antiapoptotic genes, resulting in a moderate improvement in drought resistance. The fact that control plants (Glurk) and plants transformed with $\beta$-glucuronidase (G115) did not show any improvement in drought resistance, indicates that the enhancement in resistance was specifically caused by the death suppressors and not to the indirect consequence of transformation or presence of a foreign gene.

It is unclear at this point what factors contribute to this enhancement in plant responses to drought stress in these lines. Drought stress is associated with the release of free oxygen radicals that cause degenerative reactions; disruption of membrane integrity and electrolyte leakage (McKersie et al. 1996). Severe drought stress was found also to induce protease enzymes that increase protein turnover (Ingram and Bartels 1996). Tolerance to environmental stresses has been positively correlated with the lev- 
a

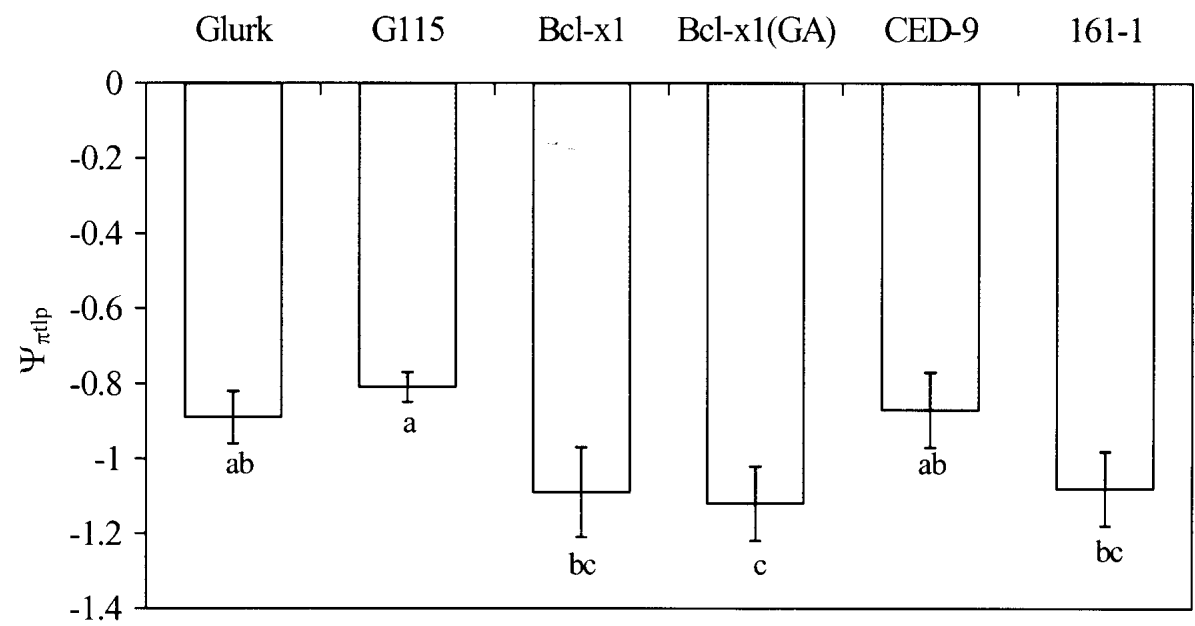

b

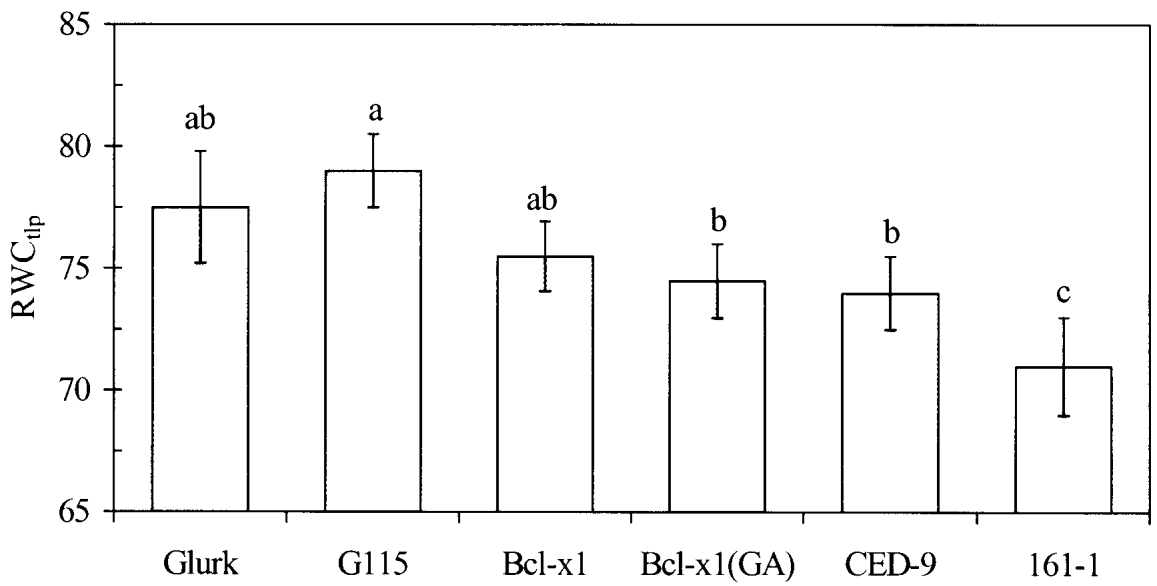

Fig. 4. Means and standard errors of osmotic potential at turgor loss point $\left(\Psi_{\pi t l p}\right)$ (a) relative water content at turgor loss point $\left(\mathrm{RWC}_{\mathrm{tlp}}\right)$ (b), and standard error bars in transformed [161-1, Bcl-x1, Bcl-x1(GA) and CED-9] and controls (Glurk and G115) tobacco plants during a dry-down period in the greenhouse. Means with similar letters are not statistically significant at $P<0.05$.

els of both antioxidant and the activities of oxygen free radical-scavenging enzymes (Bridger et al. 1994). Adams and Cory (1998) and others proposed that Bcl-2 family members can confer cell protection by preventing oxygen-induced cell death. Mitsuhara et al. (1999) found that transformation of tobacco plants with genes encoding Bcl-xl and CED-9 showed no clear electrolyte leakage when subjected to UV radiation or paraquat, a generator of reactive oxygen species, whereas wild type plants reached a maximum leakage $12 \mathrm{~h}$ after being subjected to UV radiation and were extremely sensitive to paraquat. In addition, transformed plants were found to repress chlorophyll degradation when subjected to UV radiation or exposed to paraquat herbicide.

Interest in regulation of programmed cell death has grown significantly with the establishment of their roles in devel- opment, and defense against pathogens and stress response in metazoans (Adam and Cory 1998). Cell death suppressors have been shown to inhibit cell death induced by a broad range of stresses in tissue cultures in animals (Cotter and AlRubeai 1995). In plants, these genes appear to enhance a broad spectrum of tolerances including, biotic stresses (Dickman et al. 2001), abiotic stresses (Dunigan and Dickman, unpublished data), radiation and herbicides (Mitsuhara et al. 1999), and in our study, drought, which could have a significant impact on agricultural productivity.

\section{ACKNOWLEDGMENT}

This work was supported by a grant from the University of Nebraska, Agriculture Research Division and Idun Pharmaceuticals, Inc. We thank Young-Ki Park for techni- 
cal assistance. We also thank the two anonymous reviewers for their comments, which greatly improved the manuscript.

Adams, J. M. and Cory, S. 1998. The 161-1 protein family: Arbiters of cell survival. Science 281: 1322-1326.

Augé, R. M., Schekel, K. A. and Wample, R. L. 1986. Osmotic adjustment in leaves of VA mycorrhizal and nonmycorrhizal rose plants in response to drought stress. Plant Physiol. 82: 765-770.

Bajaj, S., Targolli, J., Liu, L. F., Ho, T. H. D. and Wu, R. 1999. Transgenic approaches to increase dehydration-stress tolerance in plants. Mol. Breed. 5: 493-503.

Bianchi, M. W., Roux, C. and Vartanian, N. 2002. Drought regulation of GST8, encoding the Arabidopsis homologue of ParC/Nt107 glutatthione transferase/peroxidase. Physiol. Plant 116: $96-105$.

Berkowitz, G. A. 1998. Water and salt stress. Pages 226-237 in A. S. Raghavendra, ed. Photosynthesis - A comprehensive treatise. Cambridge University Press, New York, NY.

Boise, L. H., Garcia, M. G., Postema, C. E., Ding, L., Lindsten, T., Turka, L. A., Mao, X., Nunez, G. and Thompson, C. B. 1993. Bcl-x, a bcl-2 -related gene functions as a dominant regulator of apoptotic cell death. Cell 74: 597-608.

Bridger, G. M., Yang, W., Falk, D. E. and McKersie, B. D. 1994. Cold acclimation increases tolerance of activated oxygen in winter cereals. J. Plant Physiol. 144: 235-240.

Chaves, M. M. 1991. Effects of water deficit on carbon assimilation. J. Exp. Bot. 42: 1-6.

Cotter, T. G. and Al-Rubeai, M. 1995. Cell death (apoptosis) in cell culture systems. Trends Biotechnol. 13: 150-155.

Dickman, M. B., Park, Y. K., Oltersdorf, T., Li, W., Clemente, T. and French, R. 2001. Abrogation of disease development in plants expressing animal antiapoptotic genes. P N AS. 98: 6957-6962.

Du, Y. C., Nose, A., Wasano, K. and Uchida, Y. 1998. Responses to water stress of enzyme activities and metabolite levels in relation to sucrose and starch synthesis, the Calvin cycle and the C4 pathway in sugarcane (Saccharum sp.) leaves. Aust. J. Plant Physiol. 25: 253-260.

Ferrario-Méry, S., Valadier, M. H. and Foyer, C. 1998. Overexpression of nitrate reductase in tobacco delays droughtinduced decreases in nitrate reductase activity and mRNA. Plant Physiol. 117: 293-302.

Gross, A., McDonnell, J. M. and Korsmeyer, S. J. 1999. BCL-2 family members and the mitochondria in apoptosis. Genes Dev. 13: 1899-1911

Hengartner, M. O. and Horvitz, H. R. 1994. The ins and outs of programmed cell death in C. elegans. Philos. Trans. R. Soc. Lond. B 345: 243-246.

Hinckley, T. M, Duhme, F., Hinckley, A. R. and Richter, H. 1980. Water relations of drought hardy shrubs: osmotic potential and stomatal reactivity. Plant Cell Environ. 3: 131-140.

Ingram, J. and Bartels, I. 1996. The molecular basis of dehydration tolerance on plants. Ann. Rev. Plant Physiol. Mol. Biol. 47: 377-403.
Karakas, B., Ozias-Akins, P., Stushnoff, C., Suefferheld, M. and Rieger, M. 1997. Salinity and drought tolerance of mannitolaccumulating transgenic tobacco. Plant Cell Environ. 20: 609-616. Krampitz, M. J. and Fock, H. P. 1984. ${ }^{14} \mathrm{CO}_{2}$ assimilation and carbon flux in the Calvin Cycle and glycolate pathway in waterstressed sunflower and bean leaves. Photosynthetica 18: 1486-1488.

Kreeger, K. Y. 1996. Investigations are blossoming on programmed cell death in plants. The Scientist 10(22): 13.

Levitt, J. 1980. Responses of plants to environmental stresses. II. Water, radiation, salt and other stresses. Academic Press, New York, NY.

McKersie, B. D., Bowley, S. R., Harjanto, E. and Leprince, O. 1996. Water-deficit tolerance and field performance of transgenic alfalfa overexpression superoxide dismutase. Plant Physiol. 111: 1177-1181.

Mitsuhara, I., Malik, K. A., Miura, M. and Ohashi, Y. 1999. Animal cell-death suppressors Bcl-xl and Ced-9 inhibit cell death in tobacco plants. Current Biol. 9: 775-778.

Oberschall, A., Deak, M., Torok, K., Sass, L., Vass, I., Kovacs, I., Feher, A., Dudits, D. and Horvath, G. V. 2000. A novel aldose/aldehyde reductase protects transgenic plants against lipid peroxidation under chemical and drought stress. Plant J. 24: 437-446.

Patchepsky, L. P., Acock, B., Hoffman-Benning, S., Willmitzer, L. and Fisahn, J. 1997. Estimation of anatomical, stomatal and biochemical components of differences in photosynthesis and transpiration of wild-type and transgenic (expressing yeast-derived invertase targeted to the vacuole) tobacco leaves. Plant Cell Environ. 20: 1070-1078.

Price, A. M., Atherton, N. M. and Hendry, G. A. F. 1989. Plants under drought-stress generate activated oxygen. Free Rad. Res. Commun. 8: 61-66.

Redfield, E. B. and Zwiazek, J. J. 2000. An overview of the importance of drought resistance for survival of salt stress among black spruce planted on oil sands tailings in Alberta. Global Land Reclamation/Remediation 2000 and Beyond. Proceedings of the Canadian Land Reclamation Association's 25th Annual Meeting, 17-20 September, Edmonton, AB.

SAS Institute, Inc. 1996. SAS/STAT ${ }^{\circledR}$ user's guide. Version 6 . 12th ed. SAS Institute, Inc., Cary, NC.

Steel, R. G. D., Torrie, J. H. and Dickey, D. A. 1997. Principles and procedures of statistics: A biometrical approach. 3rd ed. McGraw-Hill Co., New York, NY. 666 pp.

Tezara, W., Fernández, M. D., Donoso, C. and Herrera, A. 1998. Seasonal changes in photosynthesis and stomatal conductance of five species from the semiarid ecosystem. Photosynthetica 35: 399-410.

Yang, E. and Korsmeyer, S. J. 1996. Molecular thanatopsis: A discourse on the Bcl2 family and cell death. Blood. 88: 386-401. 